Journal An-Nafs: Kajian Penelitian Psikologi

http://ejournal.iai-tribakti.ac.id/index.php/psikologi

e-ISSN: 2549-6166

p-ISSN: 2528-0600

\title{
EFEKTIVITAS KONSELING DENGAN PENDEKATAN COGNITIVE- BEHAVIOR THERAPY UNTUK MENINGKATKAN SELF-ESTEEM
}

\author{
Rezki Suci Qamaria \\ rezkisuciqamaria@iainkediri.ac.id \\ Institut Agama Islam Negeri (IAIN) Kediri \\ https://doi.org/10.33367/psi.v4i2.866
}

\section{Abstrak}

Self-esteem merupakan salah satu komponen penting yang membentuk kepribadian individu. Tingkat self-esteem yang dimiliki individu berkorelasi dengan perkembangan konsep diri, kepercayaan diri, motivasi diri, dan resiliensi individu. Self-esteem berkembang sejak individu terlahir di dunia. Studi kasus dalam penelitian ini membahas mengenai kondisi salah satu mahasiswa yang sedang menempuh pendidikan di Fakultas Kedokteran Universitas X Yogyakarta. Berdasarkan asesmen awal yang menggunakan tes inteligensi, tes kepribadian, dan skala self-esteem diperoleh kesimpulan bahwa subjek mengalami self-esteem rendah yang berdampak pada kepercayaan diri, motivasi, dan kemampuan resiliensi dalam mengikuti perkuliahan. Kondisi tersebut juga berdampak pada capaian akademik subjek yang kurang memuaskan. Oleh sebab itu, penelitian ini bertujuan untuk membuktikan efektivitas intervensi konseling dengan pendekatan cognitive-behavioral therapy pada subjek yang memiliki self-esteem (harga diri) yang rendah. Adapun teknik-teknik yang digunakan dalam konseling cognitive-behavioral therapy ini adalah teknik ABCDE, pertanyaan sokratik, panah vertikal, dan teknik relaksasi. Penelitian ini menggunakan metode single-case experimental design. Hasilnya adalah subjek menemukan beberapa keyakinan negatif yang membuat dirinya tidak berdaya dengan keadaan, khususnya pada aktivitas akademik. Kemudian subjek mampu menemukan keyakinan alternatif lain yang positif sehingga subjek memiliki penilaian positif kepada dirinya. Setelah melakukan proses konseling dalam beberapa sesi, subjek memiliki self esteem yang tinggi. Subjek memiliki penilaian yang positif terhadap dirinya dan tidak melihat lagi kekurangan yang dimilikinya sebagai momok yang membuat dirinya tidak berdaya dalam melaksanakan aktivitas sehari-hari, khususnya aktivitas akademik.

Kata Kunci: Konseling, Cognitive-behavior Therapy, Self-Esteem

148-181 | Journal An-nafs: Vol. 4 No. 2 Desember 2019 


\begin{abstract}
Self-esteem is one of the essential components that make up an individual's personality. The level of self-esteem possessed by an individual influences the development of self-concept, self-confidence, self-motivation, and personal resilience. Self-esteem develops since the individual realizes its function in the social environment. The case study in this study discusses the condition of one of the students currently studying at the Faculty of Medical of University $X$ of Yogyakarta. The initial assessments used are the intelligence test, personality test, and self-esteem scale. It is concluded that the subject experienced low self-esteem which had an impact on self-confidence, motivation, and resilience ability in attending lectures. This condition also affects the academic achievement of the subject, which is unsatisfactory. This study purpose is to determine the effectiveness of counseling with cognitive-behavioral therapy approach on subjects who have low self-esteem. The techniques used in cognitivebehavioral counseling therapy are ABCDE techniques, Socratic questions, vertical arrows, and relaxation techniques. This study uses a single-case experimental design method. The result is that the subject found some negative beliefs that made him helpless with the situation, especially in academic activities. Then the subject was able to find another positive alternative belief so that the subject had a positive judgment on him. After the counselling process in several sessions, the subject has high self-esteem. The subject has a positive assessment of himself and does not see his weaknesses as a scourge that makes him helpless in carrying out daily activities, especially academic activities
\end{abstract}

Keywords: Counseling, Cognitive-behavior Therapy, Self-Esteem 
Rezki Suci Qamaria | Efektivitas Konseling

\section{Pendahuluan}

Di indonesia, jurusan kedokteran adalah primadona yang sangat diminati oleh para calon mahasiswa. Kondisi tersebut terlihat pada proses penerimaan mahasiswa baru di Universitas X Yogyakarta yang memperlihatkan para calon mahasiswa berbondong-bondong mendaftar di jurusan Kedokteran. Ketika individu telah menjadi mahasiswa kedokteran maka akan dihadapkan pada bentuk pendidikan yang berupa kuliah pakar, tutorial, praktikum, kerja lapangan, konsultasi pakar, evaluasi, dan penelitian akhir. Bentuk pendidikan yang beragam dan penugasan membuat mahasiswa kedokteran rentan mengalaman tuntutan dan tekanan akademik yang dapat berdampak pada kondisi stres bahkan frustrasi. Namun apabila mahasiswa memiliki perkembangan kepribadian positif salah satunya memiliki selfesteem tinggi maka hal tersebut dapat diatasi dengan baik. Berbeda halnya jika mahasiswa memiliki self-esteem rendah, maka sangat berpotensi mengalami stres berkepanjangan yang bisa berdampak negatif pada kondisi akademik, sosial, dan emosi.

Sesungguhnya individu yang memiliki self-esteem tinggi cenderung memiliki inisiatif, resiliensi dalam menghadapi masalah, dan perasaan puas terhadap aktivitas yang dilakukannya. Sebaliknya, individu yang memiliki self-esteem rendah rentan mengalami depresi, penggunaan narkoba, dan praktek kekerasan di dalam kehidupan sehari-harinya (Rosenberg, 2015). Mruk (1995) menambahkan bahwa individu yang memiliki harga diri yang rendah umumnya memiliki perasaan inferior, takut gagal membina hubungan sosial, kesepian karena merasa diasingkan/tidak diperhatikan, kurang mampu mengekspresikan diri, pasif mengikuti lingkungan, dan merasa tidak aman. Selain itu, individu dengan harga diri rendah juga menunjukkan kecemasan yang lebih tinggi, lebih banyak menunjukkan simtom psikosomatis, dan depresi.

Harga diri (self-esteem) merupakan salah satu aspek mendasar yang membentuk kepribadian dan menentukan perilaku individu (Lumongga, 2016). Self esteem merupakan evaluasi 
seseorang terhadap dirinya sendiri secara positif dan juga sebaliknya dapat menghargai secara negatif. Gufron dan Risnawita mengatakan bahwa self esteem adalah penilaian diri yang dilakukan seseorang terhadap dirinya yang didasarkan pada hubungannya dengan orang lain (Ghufron \& Risnawita, 2010). Feist dan Feist juga menambahkan harga diri merupakan perasaan pribadi seseorang bahwa dirinya bernilai atau bermanfaat dan percaya diri (Feist \& Feist, 2010). Jadi, self esteem adalah penilaian diri yang dilakukan individu yang berasal dari persepsinya, perlakuan orang lain terhadap dirinya, dan menunjukkan sejauh mana individu memiliki rasa berharga dalam lingkungannya serta mampu berhasil dan berguna dalam hidupnya.

Apabila individu tidak menghargai dirinya maka individu tersebut diprediksi mengalami kesulitan untuk menghargai individu di sekitarnya (Srisayekti \& Setiady, 2015). Oleh karena itu, harga diri menjadi hal penting bagi pembentukan konsep diri individu yang tercermin dalam bentuk sikap dan perilaku. Namun kondisi berbeda dialami oleh salah satu mahasiswa berinisial A di fakultas kedokteran X Yogyakarta. Dimana selama menempuh pendidikan sejak Sekolah Menegah Pertama sampai bangku perkuliahan, subjek A merasa tidak memiliki sesuatu yang berharga sehingga dirinya merasa pesimis dapat berhasil menyelesaikan pendidikan.

Berdasarkan hasil asesmen psikologis (tes inteligensi, tes kepribadian, dan skala self-esteem) yang dilakukan saat pengambilan data awal diperoleh beberapa gambaran bahwa subjek merasa mengalami kesulitan memahami materi perkuliahannya yang banyak. Subjek juga tidak didukung oleh kapasitas memori jangka panjang yang bisa membantu subjek dalam mengingat dengan baik materi perkulihan. Pada lingkungan baru dan ramai subjek kesulitan menggunakan informasi yang dimilikinya ketika berinteraksi secara lisan. Hal tersebut disebabkan kondisi subjek yang kurang percaya diri untuk mengemukakan pendapat di depan orang lain (situasi diskusi dan presentasi materi di kelas). Subjek selalu berfikir bahwa ketika 
dirinya berbicara di depan umum maka apa yang akan dikatakannya aneh, keliru, dan dirinya akan ditertawai oleh temantemannya atau bahkan dimarahi oleh dosen.

Pada kondisi perkuliahan, khususnya saat tugas presentasi dan diskusi, subjek selalu khawatir dan takut menjelaskan sesuatu yang nantinya dianggap salah oleh orang lain dan orang tersebut akan menertawakan dirinya dan tidak ingin lagi berbicara dengannya. Di samping itu ketika bertemu dan berinteraksi dengan orang-orang di sekitarnya baik orang baru atau yang sudah lama dikenalnya, subjek memiliki kekhawatiran bahwa apa yang akan dikatakannya tidak dimengerti dan tidak berguna bagi orang lain. Hal tersebut akhirnya membuat subjek memiliki Kepercayaan diri yang rendah dan membuat subjek mengalami kesulitan menjalin interaksi sosial dengan orang-orang baru ditemuinya. Bahkan dalam kesehariannya subjek hanya berinteraksi dengan orangorang tertentu saja. Kondisi-kondisi tersebut pada akhirnya membuat subjek merasa tidak aman, tidak nyaman dan sedih.

Selanjutnya, subjek digambarkan sebagai pribadi yang tidak mampu mengungkapkan apa yang dipikirkan dan dirasakannya kepada orang lain, baik itu keluarga maupun teman dekatnya. Oleh karena itu dalam kesehariannya subjek terlihat pasif dalam mengikuti perkuliahan, khususnya perkuliahan dalam bentuk tutorial dan presentasi di kelas karena subjek merasa bahwa apapun yang akan dikatakannya di depan umum adalah hal yang salah dan memiliki kekhawatiran akan disalahkan. Perasaanperasaan tersebut tidak terlepas dengan perasaan yang tidak aman dalam diri subjek. Subjek memiliki rasa tidak aman atau memiliki kekhawatiran yang berlebihan ketika berada pada situasi sosial yang mempertemukan dirinya dengan orang-orang baru dan orang-orang dengan jumlah yang banyak. Oleh karena itu, secara kepribadian subjek adalah pribadi yang tertutup. Walaupun subjek memiliki teman akrab namun subjek tidak pernah mengungkapkan permasalahan yang dialaminya selama menempuh pendidikan di Fakultas Kedokteran. Subjek akan memilih diam dan hanya aktif mendengar semua keluh kesah teman akrabnya tersebut. Selain itu,

152 | Journal An-nafs: Vol. 4 No. 2 Desember 2019 
subjek termasuk pribadi yang memiliki konsep diri yang negatif karena walaupun subjek sangat menyadari apa yang menjadi kelemahan dan kelebihannya. Namun subjek tidak mampu melakukan penilaian positif terhadap apa yang menjadi kelemahan dan kelebihannya. Bahkan subjek menganggap bahwa kelemahannya membuat dirinya selalu mengalami kegagalan dan merasa tidak berharga dalam hidupnya.

Self esteem rendah yang dimiliki subjek tergambar pada pribadi subjek yang inferior atau merasa tidak memiliki kemampuan yang memadai untuk menghadapi permasalahan dalam kehidupannya. Bukti gambaran tersebut adalah subjek merasa bahwa dirinya tidak sepintar teman-teman yang lain. Hal tersebut didukung oleh pendapat Mruk (1995) bahwa individu yang memiliki harga diri yang rendah umumnya memiliki perasaan inferior atau perasaan tidak mampu ketika melakukan aktivitas sehari-hari. Lalu, subjek juga mengalami kesulitan menjalin interaksi dengan individu di sekitarnya, khususnya individu yang baru ditemuinya. Subjek memiliki kekhawatiran bahwa ketika dirinya berbicara dengan orang lain maka orang tersebut akan menilai perkataannya tidak penting, akhirnya orang tersebut tidak ingin lagi berkomunikasi dengan dirinya, dan akhirnya membuat dirinya sedih. Hal tersebut membuat subjek pasif berbicara ketika berada di antara orang banyak dan orang yang baru ditemuinya. Kondisi yang dialami subjek senada juga dengan yang dikemukakan oleh Mruk (1995) bahwa individu yang memiliki harga diri yang rendah memiliki perasaan takut gagal membina hubungan sosial dengan orang di sekitarnya.

Bukti lain yang menggambarkan subjek memiliki harga diri yang rendah adalah keadaan emosi subjek yang sulit diekpresikan ke lingkungan. Kondisi tersebut didukung oleh pendapat Mruk (1995) bahwa individu yang memiliki harga diri yang rendah memiliki ketidakmampuan dalam mengekspresikan diri baik dalam hal perasaan maupun pikiran subjek. Subjek juga pasif dalam mengikuti perkuliahan, khususnya perkuliahan dalam bentuk tutorial dan presentasi di kelas karena subjek merasa 
bahwa apapun yang akan dikatakannya di depan umum adalah hal yang salah dan memiliki kekhawatiran akan disalahkan. Perasaanperasaan tersebut tidak terlepas dengan perasaan yang tidak aman dalam diri subjek. Subjek memiliki rasa tidak aman atau kehawatiran yang berlebihan ketika berada pada situasi sosial yang mempertemukan dirinya dengan orang-orang baru dan orang-orang dengan jumlah yang banyak. Kondisi tersebut didukung oleh Mruk (1995) menjelaskan bahwa individu yang memiliki harga diri rendah mempelihatkan perasaan tidak aman secara berlebihan.

Adapun faktor yang menyebabkan subjek memiliki harga diri yang rendah adalah faktor intelegensi. Subjek yang memiliki kapasitas inteligensi di bawah dari individu seusianya berdasarkan hasil tes inteligensi (IST). Hal tersebut membuat subjek merasa bahwa dirinya tidak sepintar teman-temannya yang lain. Ditambah prestasi akademik subjek selama menjalani pendidikan di Fakultas Kedokteran sangat jauh dari kata memuaskan dan harapan subjek. Kondisi tersebut didukung oleh penjelasan Coopersmith (Ghufron \& Risnawita, 2010) bahwa individu dengan harga diri rendah memiliki skor inteligensi yang rendah, memperlihatkan usaha yang kurang dalam memecahkan sebuah permasalahan, dan prestasi akademik yang rendah pula. Coopersmith (Ghufron \& Risnawita, 2010) juga menambahkan bahwa performansi individu yang tidak sesuai dalam mencapai prestasi yang diharapkan akan berperan penting dalam pembentukan harga diri yang rendah pada individu.

Lingkungan keluarga subjek juga menjadi faktor kuat membuat subjek tumbuh menjadi pribadi yang memiliki harga diri yang rendah. Khususnya, perlakuan orangtua yang selalu mengatakan bahwa subjek adalah anak yang tidak berbakti. Jika subjek tidak melakukan sesuai apa yang dikatakan orangtuanya maka subjek akan dijuluki anak yang tidak berbakti. Orangtua juga sering membandingkan subjek dengan saudara yang lain. Mruk (1995) pun menegaskan bahwa individu yang tidak mendapatkan penghargaan di dalam keluarganya bahkan dibanding-bandingkan dengan anggota keluarga yang lain akan membentuk individu

154 | Journal An-nafs: Vol. 4 No. 2 Desember 2019 
tersebut memiliki harga diri yang rendah. Pola asuh otoriter orangtua, khususnya ayah juga memberikan pengaruh yang signifikan pada pembentukan harga diri rendah pada diri subjek. Sebagaimana dijelaskan oleh Coopersmith (Ghufron \& Risnawita, 2010) mengemukakan bahwa pola asuh yang otoriter akan mengakibatkan individu mempunyai harga diri yang rendah.

Selain itu, lingkungan sosial subjek juga menjadi salah satu pencetus subjek memiliki harga dirinya rendah. Teman-teman yang berada di sekitar subjek selalu membanding-bandingkan subjek dengan saudara yang lebih berprestasi. Teman-teman selalu menganggap subjek tidak mampu menghadapi perkuliahan. Kondisi tersebut membuat subjek merasa kemampuannya kurang dan dirinya bukanlah siapa-siapa di dalam lingkungannya. Subjek yang memiliki kepribadian tertutup/introvert hanya akan diam dan menghindar dari teman jika berada diposisi selalu dibandingbandingkan dengan oranglain. Kondisi tersebut sesuai dengan penjelasan Klass dan Hodge yaitu pembentukan harga diri dimulai dari seseorang yang menyadari dirinya berharga atau tidak (Ghufron \& Risnawita, 2010). Hal ini merupakan hasil dari proses lingkungan, penghargaan, penerimaan, dan perlakuan orang lain kepadanya. Subjek yang merasa selalu dibanding-bandingkan dengan oranglain membuat subjek memiliki harga diri yang rendah.

Selain tiga faktor tersebut, McKay dan Fanning juga mengemukakan bahwa faktor penting dalam menentukan tinggi rendahnya self esteem inidividu adalah penilaian individu itu sendiri terhadap dirinya sendiri (Indrawsari, 2012). Penilaian yang rendah terhadap diri sendiri dapat berupa pikiran negatif, kesalahan berfikir, dan pikiran yang tidak realistis. Pikiran negatif dan tidak realistis akan membuat individu melakukan proses evaluasi diri yang bias atau keliru. Kondisi tersebut juga tergambar pada diri subjek. Di mana subjek memiliki keyakinan negatif berupa global labelling ("saya tidak bisa/saya aneh"), mind reading ("orang akan menilai pembicaraan saya tidak penting), dan control 
fallacies (Saya tidak pintar makanya saya memiliki nilai yang rendah).

Akhinya berdampak pada perasaan subjek yang kurang percaya diri ketika berbicara di depan umum atau dengan orang baru ditemuinya sehingga berpengaruh pada proses akademiknya. Kondisi tersebut senada dengan pemaparan Guindon yang menjelaskan bawa individu yang memiliki self esteem rendah akan memiliki kepercayaan diri yang rendah terhadap apa yang menjadi keputusan dan pendapatnya (Hunt \& Guindon, 2010). Perasaan kurang percaya diri subjek saat berbicara di depan umum atau berinteraksi dengan orang baru didasari oleh rasa kecemasan subjek yang tinggi sehingga membuat tubuh subjek mengalami respon-respon fisik (dingin, keringatan, gemetar, mengeluarkan air mata). Kecemasan dialami subjek tersebut karena subjek tidak mampu menghargai potensi dan kemampuan yang dimilikinya dalam kehidupan sehari-hari sehingga membuat subjek berfikir bahwa apa yang dilakukan dan dikatakannya akan dinilai salah atau keliru oleh orang lain. Akhirnya berdampak juga dengan pencapaian akademik subjek selama menempuh pendidikan di Fakultas Kedokteran. Selain itu, karena subjek selama ini melakukan penilaian yang negatif kepada dirinya sendiri akhirnya subjek tumbuh menjadi pribadi dengan konsep diri negatif. Kondisi tersebut telah dijelaskan oleh Baumeister (Sarandria, 2012) bahwa self esteem sebagai aspek evaluasi di dalam konsep diri yang berhubungan dengan pandangan keseluruhan terhadap diri sebagai berharga atau tidak berharga. Jadi, jika individu memiliki self esteem yang rendah karena selalu melakukan penilaian terhadap dirinya bahwasanya dirinya tidak berharga maka kondisi tersebutlah yang mendukung pembentukan konsep diri negatif pada individu.

Berdasarkan kondisi subjek tersebut, intervensi konseling dengan menggunakan pendekatan cognitve-behavior therapy yang dianggap efektif meningkatkan self-esteem subjek agar mampu menyelesaikan proses pendidikannya di Fakultas Kedokteran sesuai hasil yang diharapkan. Wilding dan Milne (2008); 
(Lumongga, 2016) menjelaskan bahwa pendekatan cognitivebehavior therapy dapat menjadi salah satu alternatif untuk meningkatkan self esteem individu. Pendekatan tersebut membantu mengarahkan individu menyadari dan menentang pikiran-pikiran negatifnya yang membuat individu memiliki penilaian yang rendah terhadap dirinya sendiri. Pemaparan tersebut ditegaskan oleh Della dalam penelitiannya tentang cognitive-behavior therapy. Hasil penelitian tersebut menunjukkan bahwa intervensi cognitive-behavior therapy efektif meningkatkan self esteem pada mahasiswa yang mengalami distres psikologis (Della, 2012). Hal tersebut terlihat dari peningkatan self esteem dan penurunan distres psikologis serta refleksi partisipan yang menunjukkan adanya kemampuan dalam mendeteksi unhelpful thoughts yang muncul, penurunan emosi negatif yang dirasakan, dan perubahan perilaku pada partisipan. Selain itu, penelitian lain juga membuktikan hal yang sama yaitu cognitive-behavior therapy efektif mampu meningkatkan self esteem individu dewasa muda (Sarandria, 2012). Bahkan modul yang dibuat oleh Sarandria (2012) diadaptasi oleh peneliti untuk dijadikan pedoman dalam melaksanakan konseling cognitive-behavior therapy pada subjek. Konseling dengan pendekatan cognitive-behavior therapy adalah salah satu bentuk intervensi yang menekankan bagaimana masalah emosi dan perilaku dapat diatasi secara efektif melalui restrukturisasi kognitif dan mengubah keyakinan irasional dan pikiran tidak akurat melalui berbagai teknik (Corey, Corey, \& Corey, 2013).

\section{Metode Penelitian}

Gambaran subjek dalam penelitian ini adalah seorang mahasiswi yang sedang menempuh pendidikan semester akhir di Fakultas Kedokteran Universitas X yang berusia 24 tahun. Subjek berinisial A tersebut memiliki tingkat self-esteem yang rendah berdasakan asesmen awal yang telah dilakukan dengan menggunakan tes inteligensi, tes kepribadian, dan skala selfesteem. 
Adapun pendekatan yang digunakan dalam penelitian ini adalah pendekatan eksperimen dengan metode single case design. Single-case experimental design adalah design penelitian yang mengukur efek intervensi pada kasus yang dialami individu (Latipun, 2008). Analisis data menggunakan analisis kualitatif (hasil wawancara dan observasi) berupa proses pencocokan pola dan membangun penjelasan mengenai kondisi subjek sebelum mengikuti konseling, selama mengikuti proses konseling, dan setelah mengikuti konseling (Yin, 2017). Tidak hanya itu, peneliti juga memperkuat data penelitian dengan analisis kuantitatif yaitu membandingkan tingkat self-esteem subjek sebelum dan sesudah mengikuti intervensi konseling dengan pengukuran skala selfesteem.

Ketika membahas mengenai intervensi psikologi maka pembahasan akan mengacu pada tiga metode yang dapat digunakan untuk melakukan intervensi psikologis. Tiga metode tersebut adalah konseling, terapi, dan psikoedukasi (Himpunan Psikologi Indonesia, 2010). Penelitian ini menggunakan intervensi konseling dengan pendekatan cognitive-behavior therapy untuk meningkatkan self-esteem subjek A.

Berikut teknik-teknik yang digunakan dalam konseling cognitive-behavior therapy ini, yaitu:

1. Teknik ABCDE

Sarandria (2012) menjelaskan bahwa teknik yang umum dipakai dalam cognitive-behavior therapy (CBT) untuk mengidentifikasi negatif automative thoughts adalah teknik ABC. Teknik ini dikembangkan oleh Albert Ellis pada tahun 1950-an yang kemudian dikembangkan menjad ABCDE (Wilson \& Branch, 2006 dalan Sarandria, 2012). Format ABCDE terdiri dari bagian A (activating events) yaitu merepresentasikan peristiwa spesifik yang dialami individu, B (belief) yaitu merepresentasikan interpretasi individu terhadap peristiwa atau situasi tersebut, dan C (Consequence) merepresentasikan keadaan emosional atau perilaku yang muncul pada individu akibat dari interpretasinya tersebut. Pada proses terapi, 
umumnya diberikan lembar pertama yang berisi tiga kolom yang harus diisikan. Jika subjek mampu mengidentikasi pikiranpikiran dan keyakinan yang negatif, maka subjek kembali diberikan lebar yang berisi kolom D (dispute) dan E effect. Dispute berfungsi untuk menentang pikiran atau keyakinan subjek yang negatif. Effects merupakan konsekuensi dari proses dispute yang telah dilakukan (Wilson \& Branch, 2006 dalan Sarandria, 2012).

2. Pertanyaan Sokratik

Beberapa ahli berpendapat bahwa pertanyaan sokratik merupakan landasan dari terapi kognitif (Padesky dalam Sarandria, 2012). Ketika menggunakan pertanyaan sokratik dalam cognitive behavior therapy maka terapis memberikan kesempatan kepada subjek mengungkapkan apa yang sebenarnya subjek tahu namun belum disadari atau telah terlupakan. Sarandria (2012) menjelaskan bahwa pertanyaan sokratik berguna pada banyak area dalam sesi terapi antara lain:

a. Pertanyaan sokratik untuk mengidentifikasi kognisi, afeksi, dan tingkah laku subjek yang berhubungan dengan masalah subjek.

Contoh:

"Apa yang anda lakukan ketika itu terjadi?" "Apa artinya bagi anda ketika anda berpikir demikian?" "Jika itu terjadi, bagaimana perasaanmu?" "Apa yang ada dalam pikiranmu pada saat anda merasakan demikian"

b. Pertanyaan sokratik yang membantu subjek membayangkan konsekuensi dari berbagai pikiran.

Contoh:

"Bayangkan anda menganggapnya menyedihkan, lalu anda benar-benar bertemu dia. Apa yang akan terlintas dalam pikiran anda?"

c. Pertanyaan sokratik dapat membantu menantang pikiran negatif dan melakukan disputation pada lembar ABC. 
Rezki Suci Qamaria | Efektivitas Konseling

Contoh:

"Apa anda punya bukti mendukung pikiran anda tersebut?"

"Apa kerugian yang anda dapatkan ketika anda berpikir demikian?"

"Jika anda bereaksi seperti itu (reaksi alternatif), apa yang akan anda rasakan?, bagaimana teman anda bereaksi?"

d. Pertanyaan sokratik akan memandu subjek untuk menemukan pemecahan masalah yang baik.

Contoh:

"Apa yang mungkin anda akan sarankan pada teman anda jika ia menghadapi situasi seperti ini?"

3. Panah vertikal

Wilding dan Milne (2008) menjelaskan bahwa teknik ini adalah keterampilan yang cukup baik untuk menggambarkan huhungan sebab-akibat pada pikiran-pikiran yang dimiliki oleh individu. Davis (Sarandria, 2012) juga memaparkan bahwa teknik ini dapat digunakan untuk menelaah asumsi atau keyakinan negatif individu. Caranya adalah dengan mengambil salah satu dari negative automatic thoughts subjek. Misalnya: "Perasaan kamu stress, cemas, dan sakit kepala. Pikiran kamu adalah.....", Lalu respon subjek: "Saya nampaknya tidak dapat melakukan sesuatu yang saya perlukan untuk mengerjakan presentasi ini." Namun bukan jawaban tersebut yang diinginkan. Jika jawaban tersebut yang dikemukakan maka mungkin saja banyak subjek yang mengikuti terapi ini akan berhenti sampai pertanyaa tersebut. Sebaiknya terapis kembali memberikan pemahaman mengenai kondisi subjek "Anda merasa sangat stress dan anda memiliki alasan bahwa anda tidak dapat melakukan sesuatu dengan kondisi tersebut." Hal tersebut adalah sesuatu yang masuk akal. Akan tetapi ketika subjek membutuhkan pertanyaan-pertanyaan yang sifatnya menggali pikiran-pikiran negatif subjek sehingga subjek tersadar dengan pikirannya sendiri. Berikan arahan kepada subjek untuk 
bertanya kepada dirinya sendiri terkait pertanyan-pertanyaan berikut:

Pertanyaan:

"Mengapa hal itu terjadi....?"

Jawaban mungkin saja:

"Jika saya presentasi tidak berjalan dengan baik, saya

mungkin kehilangan subjek"

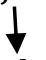

Teruskan. Bertanya kepada diri sendiri mengenai

pertanyaan:

"Mengapa hal itu terjadi....?"

Jawaban mungkin saja:

"Jika saya kehilangan subjek maka perusahan kami tidak dapat mengejar target penjualan"

Jangan berhenti. Berikan pertanyaan ketiga:

"Mengapa hal itu terjadi...?"

Jawaban mungkin saja:

"Saya akan bertanggung jawab dengan perkerjaan saya dan mungkin saya akan kehilangan pekerjaan saya"

Setelah itu, subjek kembali diberikan pemahaman bahwa: sekarang kamu mempunyai pikiran yang saling terkait sebabakibat dan sesungguhnya yang membuat kamu merasa stress, cemas, dan sakit kepala bukan karena tidak mampu melakukan pekerjaan kamu dengan baik akan tetapi karena kamu berfikir bahwa "Saya akan bertanggung jawab dengan perkerjaan saya dan mungkin saya akan kehilangan pekerjaan saya."

4. Teknik relaksasi

Prawitasari dkk (2002), relaksasi adalah salah satu teknik di dalam terapi perilaku. Ketagangan dan kecemasan yang dialami individu mampu diturunkan dengan efektif melalui penerapan teknik relaksasi ini. Secara spesifik Burns (Prawitasari dkk, 2002) memaparkan kegunaan-kegunaan yang dapat diperoleh dari latihan relaksasi yaitu individu mampu 
menghindari reaksi diri yang besar terhadap keadaan stress misalnya sakit kepala, hipertensi, dan insomnia. Selain itu berguna juga dalam mengurangi tingkat kecemasan individu, meningkatkan performance bekerja, sosial, dan keterampilan fisik, serta kesadaran fisiologis.

\section{Paparan Hasil}

Intervensi konseling dengan pendekatan cognitive-behavior therapy dilakukan selama 1 bulan yang terbagi menjadi 5 pertemuan yaitu terdiri dari 1 sesi pembukaan, 3 sesi intervensi/konseling, dan 1 sesi evaluasi \& terminasi. Berikut dipaparkan proses pelaksanaan konseling dengan pendekatan cognitive-behavior therapy pada subjek yang mengalami self-esteem rendah:

Tabel 1. Proses Pelaksanaan konseling dengan pendekatan cognitive-behavior therapy

\section{SESI AWAL (PEMBUKAAN)}

Pada sesi awal ini, konselor memaparkan terlebih dahulu Hasil Pemeriksaan Psikologis yang telah dilakukan sebelumnya. Setelah klien diberikan pemaparan hasil pemeriksaan psikologisnya, klien mengatakan bahwa semua yang dipaparkan sudah sesuai dengan apa yang dirasakan dan diyakini/dipikirkan klien tentang dirinya. Namun terdapat hal yang baru disadari klien selama ini yaitu adanya keyakinan-keyakinan negatif dalam diri klien. Klien mulai menyadari ketika konselor memberikan saran yaitu klien sebaiknya mengarahkan keyakinannya dengan berfikir positif tentang dirinya bukan malah sebaliknya selalu menilai dirinya tidak berharga dengan kekurangan yang dimilikinya. Contohnya, klien berkali-kali mengatakan kepada konselor selama proses asssesmen bahwa dirinya tidak sepintar teman-temannya makanya nilainya kecil terus. Lalu klien sendiri mengatakan bahwa keyakinan negatif itu telah mensugesti dirinya sehingga seperti tidak merasa berdaya dengan keadaan. Klien merasa bahwa dirinya yang selalu merasa tidak sepintar teman-temannya membuat dirinya pasrah dengan keadaan dan kurang semangat menghadapi proses perkuliahan. Klien pun menyadari bahwa tidak hanya dirinya yang memiliki nilai 
rendah, beberapa temannya pun sering mengulang seperti dirinya. Klien mengatakan bahwa usahanya saja yang kurang selama ini sehingga membuatnya memperoleh nilai kecil saat ujian. Dirinya sadar bahwa tidak semua orang bisa masuk kedokteran dan dirinya bisa masuk. Kondisi tersebut diartikan oleh klien bahwa ketika dirinya diterima maka dirinya dianggap mampu menghadapi perkuliahan di Fakultas Kedokteran. Setelah klien menyadari bahwa dirinya memiliki beberapa keyakinan negatif sehingga mempengaruhi penilaian klien terhadap dirinya maka klien bersedia untuk mengikuti proses konseling pada pertemuan-pertemuan selanjutnya.

\section{SESI INTERVENSI I}

Sebelum masuk ke proses penggalian pikiran otomatis, konselor memberikan lembar kerja "Apa yang membuat saya" kemudian meminta klien untuk memaparkan dan menuliskan kejadian yang berkesan dan selalu teringat dalam hidupnya membuat klien merasa merasa senang, sedih, dan marah. Klien sempat bertanya kembali mengenai apakah peristiwa yang harus dipaparkan dan dituliskan yang baru-baru saja terjadi. Konselor pun menjelaskan bahwa klien bisa menulis peristiwa-peristiwa yang telah dialami klien sepanjang hidup klien sampai sekarang. Klien Klien memulai dengan menuliskan peristiwa-peristiwa yang membuat klien senang yaitu:

a. Saat diterima masuk Fakultas Kedokteran

b. Kumpul bersama keluarga

c. Liburan dengan teman-teman

d. Bersama dengan abang

e. Dibeliin baju sama abang

Setelah menulis kejadian yang membahagiakan, klien kemudian mengarahkan tangannya untuk menulis di kolom "sedih" terlihat wajah dan kepala klien ditundukkan sambil menulis kejadian pertama yaitu "melihat abah marah." Klien pun tiba-tiba menangis dan menggeleng-gelengkan kepalanya kepada konselor dan mengatakan "mbak saya sudah tidak bisa menulis lagi, mbak saja yang tulis." Konselor mengambil lembar yang diberikan klien dan mengatakan kepada klien "Kamu sedih banget yah, kalau kamu melihat abah marah", klien menjawab "Iya, dulu abah sangat tegas, permasalahan sedikit saja ayah bisa sangat marah ke anaknya, enggak tau kenapa abah bisa seperti itu keanak-anaknya. Kejadian lain yang membuat klien sedih adalah: 
a. Selalu mendapatkan nilai kecil saat ujian

b. Selalu dibanding-bandingkan dengan abang

c. Kesulitan berbicara di depan orang banyak

d. Kesulitan berbicara dengan orang-orang baru ditemui.

e. Sebelum menulis di kolom "marah", klien mengatakan bahwa dirinya jarang marah besar dan untuk marah yang biasa itu tidak pernah di simpan lama di hati. etelah beberapa detik, klien pun mengatakan bahwa sebenarnya dirinya memiliki kemarahan kepada dirinya sendiri yang sering menunda-nunda melakukan suatu pekerjaan atau tugas.

Setelah klien selesai mengerjakan lembar "Apa yang membuat saya..", klien kemudian diajak untuk membahas lembar kerja selanjutnya yaitu lembar "catatan keyakinan."

Kolom A (Peristiwa): Untuk menggiring klien menyadari dan memahami keyakinan negatif maka konselor meminta klien memilih salah satu kejadian yang telah dituliskan untuk dituliskan di kolom A. Klien pun memiliki kolom "sedih" yaitu kejadian "melihat abah marah." Konselor kemudian meminta klien untuk menjelaskan secara spesifik kejadian abah marah yang membuat klien merasa sedih. Sambil tersedu-sedu karena menangis, klien memulai menceritakan "Abah itu dulu waktu kita masih kecil selalu marahin anak-anaknya kalau berbuat salah. Walaupun kita buat masalah kecil dan ketahuan abah, abah langsung marah besar. Kalo abah marah tidak hanya suaranya yang besar tetapi juga main tangan keanaknya, termasuk anak-anaknya yang cewek, saya dan kakak. Kalo abah sudah marah ibu sering membela tapi lama kelamaan ibu tidak bisa membela lagi. Abah itu tegas banget mbak.

Kolom B (Keyakinan): Klien yang masih menangis terseduhseduh dan menundukkan kepalanya kemudian diminta oleh konselor untuk menjelaskan apa yang dipikirkan klien ketika berada pada kejadian abah yang sedang marah besar. Ketika konselor selesai menanyakan hal tersebut, suara isakan tangis klien semakin terdengar. Akhirnya konselor meminta klien untuk mengeluarkan segala perasaan dan pikan yang dipendam klien yang membuat klien merasa sangat sedih. Setelah beberapa detik terdiam, klien mulai mengucapkan bahwa "setiap kali abah amarah dirinya sangat sedih dan selalu merasa bahwa kok ayah suka banget marah?, abah tidak sayang dengan anaknya, abah tidak sayang dengan aku, abah tidak sayang dengan abang. Klien 
mengatakan bahwa dulu sampai sekarang dirinya selalu memikirkan hal tersebut. Kolom C (Perasaan): Klien yang masih menunduk kemudian diminta untuk mengemukakan apa yang dirasakanya ketika klien berada pada peristiwa tersebut dan klien lansung mengatakan "yah sedih banget mbak.. sedihnya itu seperti sekarang, setiap kali mengingat wajah abah marah dan ingat abang, saya langsung seperti ini nangis." Lalu konselor meminta klien menyebutkan seberapa besar perasaan sedih klien ketika mengingat peristiwa tersebut, jika diskalakan 1-10, semakin besar angkanya semakin sedih dan klien menyebutkan angka 8 yang menggambarkan kesedihannya.

Setelah semua kolom diisi oleh konselor sesuai permintaan klien dan pemaparan klien maka konselor kembali memberikan lembar kerja tersebut kepada klien. Lalu klien diminta untuk memikirkan mengenai pikiran-pikiran yang telah dipaparkan sebelumnya. Klien diminta mengidentifikasi keyakinan positif dan negatif yang dimiliki oleh klien. Klien kemudian memberikan 1 tanda positif pada keyakinan klien dan tiga tanda negatif pada keyakinan klien. Lalu konselor kemudian meminta klien untuk memberikan nilai 1-10 mengenai seberapa besar klien mempercayai keyakinan tersebut. Klien memberikan skala yang sama besarnya untuk ketiga keyakinannya tersebut yaitu 8 .

Konselor kemudian menanyakan kembali kepada klien mengenai perasaan dan tindakannya ketika keyakinan tersebut muncul. Klien menjelaskan bahwa dirinya hanya bisa diam dikamar atau memeluk ibunya jika keyakinan negatifnya muncul ketika abah marah. Lalu konselor kembali bertanya apakah semua keyakinan negatif klien tersebut memang seperti itu kenyataannya atau hanya sekedar pikiran klien. Klien pun menggeleng-gelengkan kepala sambil mengusap hidung dan matanya dengan menggunakan tissu.

Lembar kerja yang sama kembali diberikan kepada klien. Konselor meminta klien untuk melakukan latihan mengerjakan lembar kerja tersebut. Pada latihan kedua ini, terlihat klien langsung menuliskan dua situasi menurut klien memiliki kesan yang sangat mendalam untuk dirinya. Situasi yang pertama dipilih klien adalah "ketika mengikuti tutorial", Klien mengatakan bahwa situasi tersebut membuat klien merasa tidak nyaman ketika harus menempuh perkuliahan dengan bentuk tutorial karena kuliah tutorial menuntut semua mahasiswa bisa aktif berbicara. Ketika berada pada situasi kuliah tutorial klien 
memiliki keyakinan bahwa "saya merasa beda dengan yang lain, dan kenapa yang lain bisa saya enggak." Semua pikiran tersebut dinilai klien sebagai keyakinan negatif. Lalu klien langsung menulis di dalam kolom perasaan bahwa dirinya merasa sedih dengan skala 6 jika berada pada situasi dan memiliki pikiranpikiran negatif tersebut. Latihan pengisian lembar kerja untuk kedua klienya ini memperlihatkan klien semakin mahir mengisi lembar kerja tersebut.

Setelah semua kolom terisi dan klien telah memahami cara mengisi lembar kerja tersebut. Maka klien diberikan tugas rumah untuk lembar kerja yang sama. Klien diminta untuk mengambil beberapa peristiwa dan menggali keyakinan negatif yang dimiliki oleh klien. Akhirnya klien telah menyelesaikan seluruh rangkaian konseling dan pelaksanaan konseling sesi pertama di akhiri dengan mengingatkan kepada klien untuk mengerjakan lembar kerja yang diberikan.

\section{SESI INTERVENSI II}

Setelah mengecek pekerjaan rumah klien, konselor mengarahkan klien untuk memulai melaksanakan konseling sesi kedua yang tujuannya adalah untuk menemukan keyakinan klien yang negatif klien yang lainnya dan bagaimana mengubah keyakinan tersebut menjadi positif. Sebelumnya, konselor kembali menjelaskan terlebih dahulu apa yang dimaksud dengan keyakinan dasar. Setelah itu konselor membantu klien menggali keyakinan dasarnya dengan memilih satu pikiran otomasti negatif yang dimiliki oleh klien. Klien pun memilih "saya takut salah berbicara di depan umum." Lalu konselor bertanya "jika kamu berfikir seperti itu, apa artinya bagi kamu?, Klien menjawab "saya selalu berpikir saya akan salah, saya akan ditertawakan, dan dianggap aneh mbak kalau bicara makanya saya itu lebih baik diam saja." Lalu konselor bertanya "apa manfaatnya untuk kamu?". Klien menggeleng-gelengkan kepala dan mengatakan "bukannya bermanfaat tetapi merugikan mbak." Konselor bertanya kembali "nah kamu bilang merugikan, memang apa hal merugikan terjadi pada diri kamu jika kamu berpikir demikian?". Klien pun menjawab "yah...semakin tidak bisa berbicara di depan orang banyak mbak, semakin terpuruk dan pasif di dalam kelas." Konselor bertanya lagi "tadi kamu mengatakan bahwa jika kamu berbicara di depan umum kamu akan berpikir bahwa kamu akan salah, akan ditertawakan, dan dianggap aneh, menurumu apakah itu keyakinan dasar yang kamu miliki selama ini?." Klien nampak 
menganggukkan kepalanya sambil mengatakan "iya yah mbak, saya itu selalu merasa seperti itu selama ini."Akhirnya klien mendapatkan insight mengenai keyakinan dasar yang dimilikinya selama ini sehingga membuat dirinya mengalami kesulitan berbicara di depan umum.

Setelah klien menyadari apa keyakinan dasarnya selama ini, konselor kemudian mengarahkan klian untuk menantang keyakinan dasar negatifnya tersebut. "Sekarang kamu sudah tahu kan keyakinan dasar negatif yang kamu miliki? Sekarang mbak akan mengarahkan kamu untuk menantang kayakinan negatifmu itu menjadi keyakinan positif. Jika keyakinan negatifmu ini tidak dirubah menjadi positif maka keyakinan negatif ini yang akan terus menerus memanggil pikiran otomatis negatif kamu dan membuat kamu selalu memunculkan aturan dan asumsi negatif dalam kehidupan sehari-hari kamu." Jadi walaupun sebelumnya kita telah menantang pikiran, aturan, dan asumsi negatif kamu tetapi keyakinan dasar kamu tetap negatif maka semuanya tidak ada perubahan. Oleh karena itu, kita akan melakukan latihan untuk menantang pikiran negatifmu itu. Cara menantang pikiran negatif tersebut adalah dengan menggunakan lembar kerja "menyesuaikan keyakinan dasar" dengan menggunakan teknik panah vertikal. Klien pun langsung mengisi bagian awal lembar kerja tersebut yaitu keyakinan negatif yang ingin disesuaikan adalah "saya akan salah, ditertawakan, dan dianggap aneh jika berbicara di depan umum." Klien meyakini kepercayaannya tersebut dengan skala 10 dan memiliki perasaan takut, marah, sedih, dan cemas jika memikirkan keyakinannya tersebut. Lalu klien membuat keyakinan baru yang akan menyeimbangkan perasaannya yaitu "jika saya berbicara tidak terjadi sesuatu dengan saya" dengan skala keyakinan sama dengan keyakinan lama yaitu 10 serta perasaannya menjadi senang, lega, dan puas. Selanjutnya klien diminta untuk mengemukakakn bukti terkait keyakinan lama yang dimilikinya. Klien pun menggelenggelengkan kepala sambil tersenyum dan mengatakan "tidak ada mbak." Konselor kembali bertanya "apakah yang menjadi keyakinanmu itu semua pernah kamu alami?, klien menjawab "belum pernah mbak." Lalu konselor bertanya lagi "lantas kenapa kamu pertahankan keyakinanmu tersebut?, klien menjawab "yah karena merasa khawatir duluan itu mbak, makanya selalu berpikir macem-macem." "Apakah keyakinan lama ini pantas dipertahankan?, klien menjawab "yah tidak mbak, merugikan." 
Kembali ke keyakinan baru klien yang positif, klien mnegatakan bahwa keyakinan baru tersebut memiliki bukti kenapa harus dipertahankan yaitu sehari sebelum melakukan konseling, klien telah mencoba untuk menjadi ketua tuorial dan berbicara di awal dan hasilnya adalah tidak ada teman yang menertawakan dirinya dan menganggap dirinya aneh, yang ada hanya rasa senang dirasakan oleh klien dan diakhir kuliah tutorial klien tertawa dan merasa bangga dengan dirinya sendiri karena ternyata bisa melakukan hal yang dianggapnya sulit untuk dilakukannya. Klien berharap untuk kedepannya klien selalu membuktikan keyakinan barunya tersebut dengan ditandai dirinya mampu berbicara di depan orang banyan dnegan lancar. Adapun tingkah laku yang kelak sebagai bukti dan mendukung keyakinan barunya adalah dengan aktif berbicara kerika tutorial, presentasi, dan berbicara dengan orang baru. Di akhir lembar kerja, klien menuliskan bahwa sebelum ditantang keyakinan lama klien sebesar 10 dan setelah ditantang menjadi 0 dan keyakinan baru klien tetap konsisten dengan skala sebesar 10 . Setelah lembar kerja tersebut selesai diisi oleh klien, konselor bertanya kepada klien bagaimana perasaannya ketika keyakinan lama itu telah ditantang dengan keyakinan baru yang lebih positif. Klien menjawab bahwa dirinya merasa senang dan nyaman jika selalu berpikir positif dalam menjalani setiap kegiatannya, khususnya kuliah tutorial. Setelah klien paham dengan proses menantang keyakinan lama yang negatif maka konselor memberikan klien tugas rumah berupa lembar kerja yang sama yaitu "menyesuaikan keyakinan dasar." Tugas tersebut akan dikumpul dan dibahas di awal pertemuan selanjutnya.

\section{SESI INTERVENSI III}

Sebelum membahas mengenai tujuan sesi ketiga, konselor terlebih dahulu memeriksa dan membahas tugas rumah klien pada pertemuan sebelumnya. Klien telah mampu menantang sendiri keyakinan dasar negatifnya dnegan menggunakan lembar kerja yang diberikan oleh konselor. Klien oun mengatakan bahwa keyakinan barunya tersebut sudah mulai untuk diterapkan yaitu "selesaikan tugas secepatnya agar tidak menumpik di akhir dan hasilnya akan maksiman.". Secara umum dapat disimpulkan bahwa klien telah mampu memahami apa yang menjadi keyakinan dasar yang negatif dimilikinya dan mampu menantang keyakinan tersebut serta membuat keyakinan baru yang lebih positif. 
Setelah itu, konselor mengarahkan proses konseling ke tujuan inti sesi keempat ini dengan mengatakan "Pada sesi-sesi sebelumnya, kamu sudah menantang dan mengubah pikiran otomatis, aturan, asumsi, dan keyakinan dasar negatif menjadi lebih positif, nah... sekarang tiba lah waktunya kita akan membahas hal-hal positif yang ada pada diri kamu dan bagaimana meningkatkan hal positif tersebut." Lalu konselor memberikan klien lembar kerja "Karakteristik positif saya" dan meminta klien untuk menuliskan karakter-karakter positif yang dimiliki klien. Klien pun menuliskan karakteristik positif yang ada dalam dirinya: "ramah, suka senyum, gak suka mengungkitungkit masalah, selalu welcome kalau mau berteman, baik (gak suka buat masalah sama teman), senang menjadi pendengar, dan senang menolong." Lalu klien kembali diberikan lembar kerja untuk menuliskan hal positif yang pernah terjadi dalam hidup klien. Sebelum menulis, klien bertanya kepada konselor "apapun itu mbak", konselor mengatakan "iyya dek." Klien pun langsung mengisi lembar kerja tersebut dan menulis beberapa hal positif: "Ketemu teman seangkayan selalu menegur, kalau ada masalah dengan teman yang meminta maaf duluan adalah saya, membantu abah jaga toko, nganterin umi berbelanja dan jalan, ramah dengan karyawan kampus, selalu rajin kuliah dan jarang absen, temen minta tolong (temenin belanja, minta anter) selalu di tolong, dan mendengarkan teman bercerita tentang kuliah dan cowok." Lalu klien kembali diarahkan untuk menuliskan kegiatan-kegiatan yang dilakukan klien dalam jurnal positif. Klien diminta menuliskan kegiatannya selama 24 jam sebelum klien bertemu dengan konselor. Klien pun menuliskan semua kegiatannya tanpa ada kendala kemudian klien diarahkan untuk melihat aspek positif yang ada dalam setiap kegiatannya dan dapat disimpulkan bahwa klien menilai kegiatan sehari-harinya dominan dimanfaatkan untuk beribadah, mendisiplinkan diri untuk tidak terlambat pergi kuliah, memanfaatkan waktu untuk melatih diri terbiasa berbicara di depan umum, dan loyal dengan temannya. Aspek-aspek positif itulah yang disadari klien muncul dalam kesehariannya selama ini yang belum disadari sebelumnya. Klien juga diminta untuk memaparkan kegiatan menyenangkan yang selama ini dilakukan klien. Klien pun menuliskan : "Futsal, nonton, jalan bareng teman, tidur, di rumah, nongkrong bareng teman." 
Setelah klien mampu mengidentifikasi karakter positifnya, hal positif yang terjadi dalam hidupnya, aspek positif yang ada dalam setiap kegiatan sehari-harinya, dan kegiatan yag menyenangkan bagi dirinya maka klien diarahkan untuk menguatkan aspek positif yang ada pada diri klien dengan menggunakan karakteristik posistifnya dan kegiatan yang menyenangkan bagi dirinya. Setelah mampu merumuskan cara menguatkan aspek positif klien. Klien lalu diberikan jurnal positif untuk dikerjakan di rumah setiap hari selama satu minggu.

Sebelum mengakhiri konseling, konselor mencontohkan klien melakukan teknik relaksasi dengan tambahan calming picture. Sebelumnya teknik relaksasi pernafasan telah diberikan kepada klien pada setiap pelaksanaan sesi intervensi sehingga klien tidak mengalami kesulitam memahami instruksi yang diberikan oleh konselor. Klien pun mngatakan bahwa dirinya tidak mengalami kesulitan melakukan kedua teknik tersebut dan kedua tekni itu akan digunakan klien jika berada pada situasi yang membuat dirinya cemas seperti sebelum memulai kuliah tutorial.

\begin{tabular}{l} 
SESI EVALUASI DAN TERMINASI \\
\hline Evaluasi dilakukan dengan cara wawancara singkat dan \\
pemberian lembar evaluasi mengenai manfaat yang dirasakan \\
klien setelah mengikuti keseluruhan program intervensi.
\end{tabular}

a. Klien berpendapat bahwa dirinya mengalami perubahan cara berfikir yang lebih positif dari sebelumnya yang banyak memiliki pikiran negarif. Kondisi tersebut akhirnya membuat klien merasa lebih lancar berbicara saat tutorial dan muali mencoba bercerita ke temantemannya. Selain itu, klien juga merasa kepercayaan dirinya sudah mulai meningkat untuk berbicara di depan orang banyak atau dalam situasi diskusi.

b. Klien berpendapat bahwa latihan-latihan yang sida dilakukannya selama sesi intervensi teah membuat klien lebih memahami dirinya, khususnya klien merasa memiliki beberapa kelebihan yang bisa menjadi modal klien untuk mengatasi kesulitan yang dialaminya dalam proses perkuliahan.

c. Klien juga berpendapat bahwa sebelum intervensi dirinya memiliki banyak rasa ketakutan dan kekhawatiran yang membuat dirinya tidak mau mencoba sesuatu dan setelah intervensi klien sudah bisa mencoba 
untuk melakukan dengan perasaan percaya diri. Misalnya, dahulu memiliki kekhawatiran dan ketakutan berbicara di depan orang banyak sekarang dicoba untuk dilakukan dengan kepercayaan diri dan hal itu membuat klien merasa puas dan bangga dengan dirinya sendiri.

d. Klien juga mengemukakakn bahwa manfaat lain yang dirasakannya selama mengikuti proses konseling adalah dirinya lebih bisa mengatur waktu dan bisa membandingkan mana yang lebih bermanfaat atau yang lebih positif bagi dirinya.

e. Klien juga mengatakan bahwa semenjak mengikuti proses intevensi dirinya sudah mencoba untuk berbicara dengan orang baru dan tidak bediam diri saja jika berada dalam sebuah kelompok.

Hal yang mengesankan bagi klien selama proses intervensi adalah ketika menjalani sesi kedua. Dimana klien menyadari beberapa pikiran negatifnya dan ketika diberikan teknik relaksasi, klien merasa lega dan senang dengan pikiran-pikiran positif yang membuat klien akhirnya memiliki keyakinan yang positif.

Berdasarkan pengukuran skala, sebelum subjek diberikan intervensi konseling dengan pendekatan cognitive-behavior therapy, subjek terlebih dahulu diberikan skala self esteem untuk mengukur tingkat self esteem subjek dengan menggunakan Rosenberg Self Esteem Scale dan hasilnya adalah subjek memiliki tingkat self esteem rendah dengan skor 13. Ketika subjek selesai diberikan konseling, subjek kembali diberikan skala yang sama untuk melihat apakah intervensi konseling yang diberikan efektif untuk meningkatkan self esteem subjek. Hasil pengisian skalanya memperlihatkan subjek mengalami perubahan self esteem yang sebelumnya berada pada kategori rendah menjadi sedang (skor 25).

Tabel 2. Hasil Intervensi Konseling Cognitive-behavior Therapy

\begin{tabular}{|c|c|c|c|}
\hline \multicolumn{2}{|c|}{ Pre-test } & \multicolumn{2}{c|}{ Post-test } \\
\hline Skor total & Kategori & Skor total & Skor total \\
\hline 13 & Rendah $(>15)$ & 25 & $\begin{array}{c}\text { Sedang } \\
(>15<25)\end{array}$ \\
\hline
\end{tabular}


Rezki Suci Qamaria | Efektivitas Konseling

\section{Pembahasan}

Hasil dari proses konseling yang telah dilaksanakan menggambarkan bahwa subjek yang awalnya memiliki penilaian negatif kepada dirinya telah mampu mengubah pikirannya melalui latihan-latihan yang ada dalam sesi konseling menjadi penilaian positif kepada dirinya. Perubahan penilaian tersebut tidak terlepas dari proses perubahan kognisi subjek yaitu pikiran otomatis negatif, aturan dan asumsi negatif, serta keyakinan yang negatif menjadi pikiran otomatis positif, aturan dan asumsi positif, serta keyakinan yang positif. Kondisi tersebut sejalan dengan hasil penelitian yang telah dilakukan Sarandria (2012) bahwa intervensi konseling dengan pendekatan cognitive-behavior therapy yang diberikan kepada individu yang memiliki penilaian negatif kepada dirinya dan akhirnya menyebabkan individu tersebut memiliki self esteem rendah mampu merubah penilaian individu tersebut menjadi lebih positif dan meningkatkan self esteem individu tersebut. Dimana penilaian inidividu dalam hal ini terletak pada kognisinya yang tertuang dalam bentuk pikiran otomatis, aturan dan asumsi, serta keyakinan dasar. Penelitian yang dilakukan oleh Nur, Dini, dan Fenny juga menyimpulkan bahwa intervensi dengan pendekatan cognitive-behavior therapy efektif membantu individu melakukan penilaian positif terhadap dirinya sehingga merasa berharga dalam lingkungan sosialnya (Islamiah, Daengsari, \& Hartiani, 2015).

Selain itu, berdasarkan evaluasi melalui wawancara dan pengisian kuesioner diperoleh data bahwa selama mengikuti proses konseling subjek mengalami perubahan cara berfikir lebih positif dari sebelumnya yang banyak memiliki pikiran negatif dan pada akhirnya subjek merasa memiliki keyakinan yang positif juga. Kondisi tersebut akhirnya membuat subjek merasa lebih lancar berbicara saat tutorial dan mulai mencoba bercerita ke temantemannya. Selain itu, subjek juga merasa kepercayaan dirinya sudah mulai meningkat untuk berbicara di depan orang banyak atau dalam situasi diskusi. Ketika berbica di depan orang banyak

172 | Journal An-nafs: Vol. 4 No. 2 Desember 2019 
tidak lagi ingin menangis melainkan merasa lega dan badannya terasa hangat.

Latihan-latihan yang sudah dilakukannya selama sesi konseling telah membuat subjek lebih memahami dirinya, khususnya subjek merasa memiliki beberapa kelebihan yang bisa menjadi modal subjek untuk mengatasi kesulitan yang dialaminya dalam proses perkuliahan. Selain itu, subjek juga memaparkan bahwa sebelum melaksanakan konseling, dirinya memiliki banyak rasa ketakutan dan kekhawatiran yang membuat dirinya tidak mau mencoba sesuatu. Namun setelah menjalani proses konseling subjek sudah bisa mencoba untuk melakukan dengan perasaan percaya diri. Misalnya, dahulu memiliki kekhawatiran dan ketakutan berbicara di depan orang banyak sekarang dicoba untuk dilakukan dengan kepercayaan diri (berbicara diawal tanpa ditunjuk) dan hal itu membuat subjek merasa puas dan bangga dengan dirinya sendiri. Subjek juga melihat respon temannya yang terharu dan bangga kepada dirinya yang sudah mulai aktif dalam tutorial. Apa yang dirasakan dan dikatakan oleh subjek sejalan dengan hasil pengamatan yang dilakukan oleh salah satu teman dekat subjek yaitu AS. AS menjelaskan bahwa subjek mulai terbuka dengan dirinya. Subjek sudah mampu menceritakan kegiatankegiatannya kepada AS. Kondisi-kondisi terkait meningkatnya kepercayaan diri subjek tersebut sesuai dengan hasil penelitian yang dilakukan oleh Wahyu dan Hardi. Penelitian tersebut menyimpulkan bahwa terdapat kenaikan skor tingkat percaya diri individu setelah diberikan perlakuan berupa konseling dengan pendekatan cognitive-behavior therapy yaitu teknik cognitive defusion (Saputra \& Prasetiawan, 2018). Penelitian yang dilakukan oleh Ryan juga telah membuktikan bahwa konseling dengan pemodelan kognitif efektif meningkatkan kepercayaan diri individu (Pandu Wiyata, 2019) dan penelitian yang dilakukan oleh Dyesi pun telah membuktikan bahwasanya konsep behavioral therapy dalam meningkatkan rasa percaya diri pada pelajar (Kumalasari, 2017). AS juga memaparkan bahwa subjek sudah tidak mengalami kecemasan ketika berinteraksi dengan orang lain. 
Bahkan dalam perkuliahan subjek sudah tidak mengalami kecemasan ketika dihadapkan pada tugas yang mengharuskan subjek tampil dan berbicara di depan kelas. Hal tersebut sesuai dengan hasil penelitian yang dilakukan oleh Mahasri dan Juliani yang menjelaskan bahwa konseling dengan pendekatan kognitif mampu menurunkan tingkat kecemasan individu, khususnya kecemasan ketika berinteraksi dengan individu lain dan kecemasan akademik (Shobabiya \& Prasetyaningrum, 2017). Penelitian terbaru juga telah dilakukan oleh Dominikus menyimpulkan bahwa kecemasan akademik yang dialami mahasiswa disebabkan adanya distorsi kognitif yaitu core belief maladaptif. Oleh karena itu layanan konseling dengan pendekatan CBT dapat dijadikan alternatif untuk membantu mahasiswa mengembalikan fungsi kognitifnya sehingga dapat mengoptimalkan kemampuannya (Situmorang, 2018).

Subjek juga mengemukakan bahwa manfaat lain yang dirasakannya selama mengikuti proses terapi adalah dirinya lebih bisa mengatur waktu dan bisa memilih perilaku mana yang lebih bermanfaat atau yang lebih positif bagi dirinya. Subjek juga mengatakan bahwa semenjak mengikuti proses konseling dirinya sudah mencoba untuk berbicara dengan orang baru dan tidak berdiam diri saja jika berada dalam sebuah kelompok. Adapun hal yang mengesankan bagi subjek selama proses konseling adalah ketika menjalani sesi kedua. Dimana subjek menyadari beberapa pikiran negatifnya dan ketika diberikan teknik relaksasi, subjek merasa lega dan senang dengan pikiran-pikiran positif yang telah ditemukannya sendiri. Selanjutnya, peneliti kembali mengukur self esteem subjek saat melakukan follow-up untuk melihat apakah perubahan yang terjadi konsisten menetap pada diri subjek. Hasilnya adalah skor pengukuran skala self esteem subjek meningkat menjadi 29 pada kategori self-esteem tinggi. Berikut tabel hasil pengukuran self esteem subjek secara keseluruhan (pre, post, dan follow-up):

174 | Journal An-nafs: Vol. 4 No. 2 Desember 2019 
Rezki Suci Qamaria | Efektivitas Konseling

Tabel 3. Hasil Follow-up

\begin{tabular}{|c|c|c|c|c|l|}
\hline \multicolumn{2}{|c|}{ Pre-test } & \multicolumn{2}{c|}{ Post-test } & \multicolumn{2}{c|}{ Follow-up } \\
\hline \multirow{2}{*}{13} & Kategori & $\begin{array}{c}\text { Skor } \\
\text { total }\end{array}$ & $\begin{array}{c}\text { Skor } \\
\text { total }\end{array}$ & $\begin{array}{c}\text { Skor } \\
\text { total }\end{array}$ & $\begin{array}{l}\text { Skor } \\
\text { total }\end{array}$ \\
\hline & $\begin{array}{c}\text { Rendah } \\
(\mathrm{X}>15)\end{array}$ & 25 & $\begin{array}{c}\text { Sedang } \\
(15>\mathrm{X}<2 \\
5)\end{array}$ & 29 & $\begin{array}{l}\text { Tinggi } \\
(\mathrm{X}>25)\end{array}$ \\
\hline
\end{tabular}

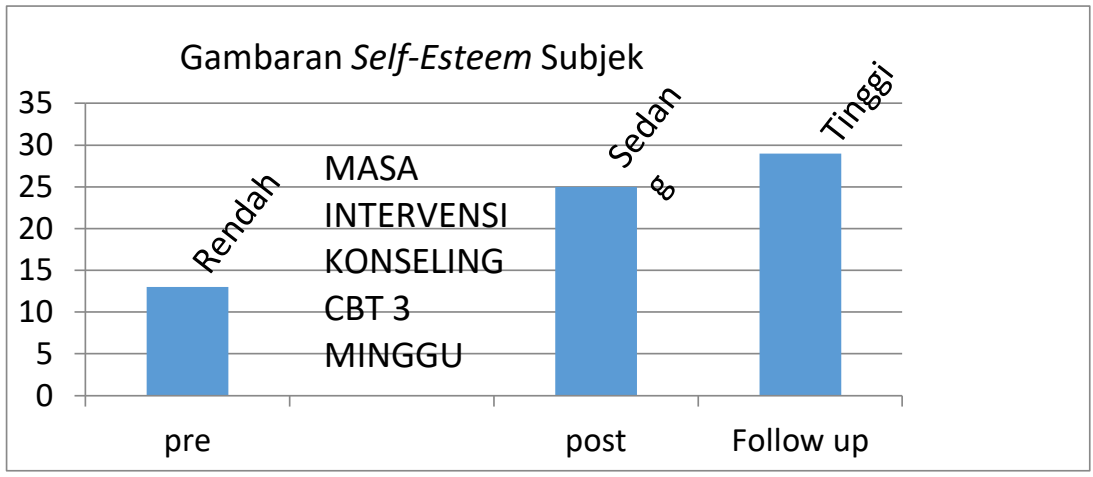

Gambar 1. Grafik Hasil Konseling Cognitive-behavior Therapy

Selain itu, peneliti juga melakukan wawancara dengan subjek mengenai aktivitas subjek setelah mengikuti intervensi (CBT). Subjek menjelaskan bahwa setelah mengikuti terapi dirinya langsung disibukkan dengan persiapan KKN, subjek diterjunkan ke lokasi KKN. Sejauh ini subjek belum menghadapi kesulitan dalam menjalani aktivitas KKNnya. Subjek dan 4 orang temannya yang berasal dari fakultas yang berbeda bisa saling bertukar pikiran mengenai ide-ide program kerja untuk kelompoknya. Tidak ada hambatan yang dialami subjek untuk berkomunikasi dan berinteraksi dengan orang-orang di desa tempat KKNnya. Bahkan subjek telah merancang dua program individu yang berkaitan dengan jurusannya dan langsung berinteraksi dengan masyarakat yaitu program penyuluhan hidup bersih dan sehat untuk anakanak sekolah dasar dan konsultasi tekanan darah untuk warga. Peningkatan self-esteem yang dialami subjek setelah mengikuti 


\section{Rezki Suci Qamaria | Efektivitas Konseling}

proses konseling dengan pendekatan CBT senada dengan hasil penelitian yang dilakukan oleh Tri, Muswardi, dan Shinta yang menyimpulkan bahwa self-esteem siswa dapat ditingkatkan menggunakan layanan konseling (Ayuevita, Rosra, \& Mayasari, 2014). Disamping itu, Bakhrudin juga menyimpulkan bahwa selfesteem individu dapat ditingkatkan dengan memberikan layanan konseling yang mengggunakan pendekatan CBT baik secara kelompok maupun secara individu (Habsy, 2017).

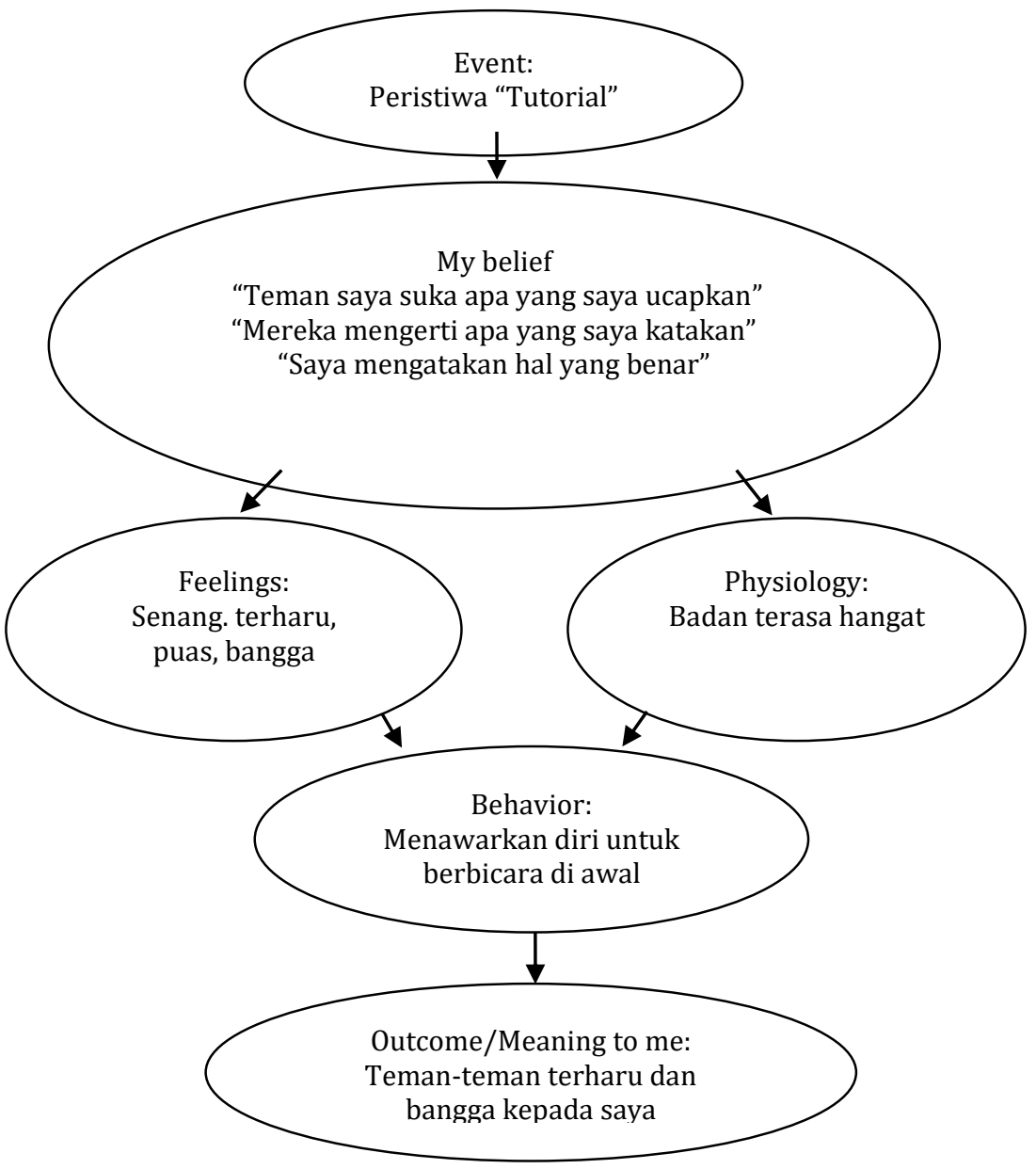

Gambar 3. Model kognitif subjek setelah konseling CBT 
Rezki Suci Qamaria | Efektivitas Konseling

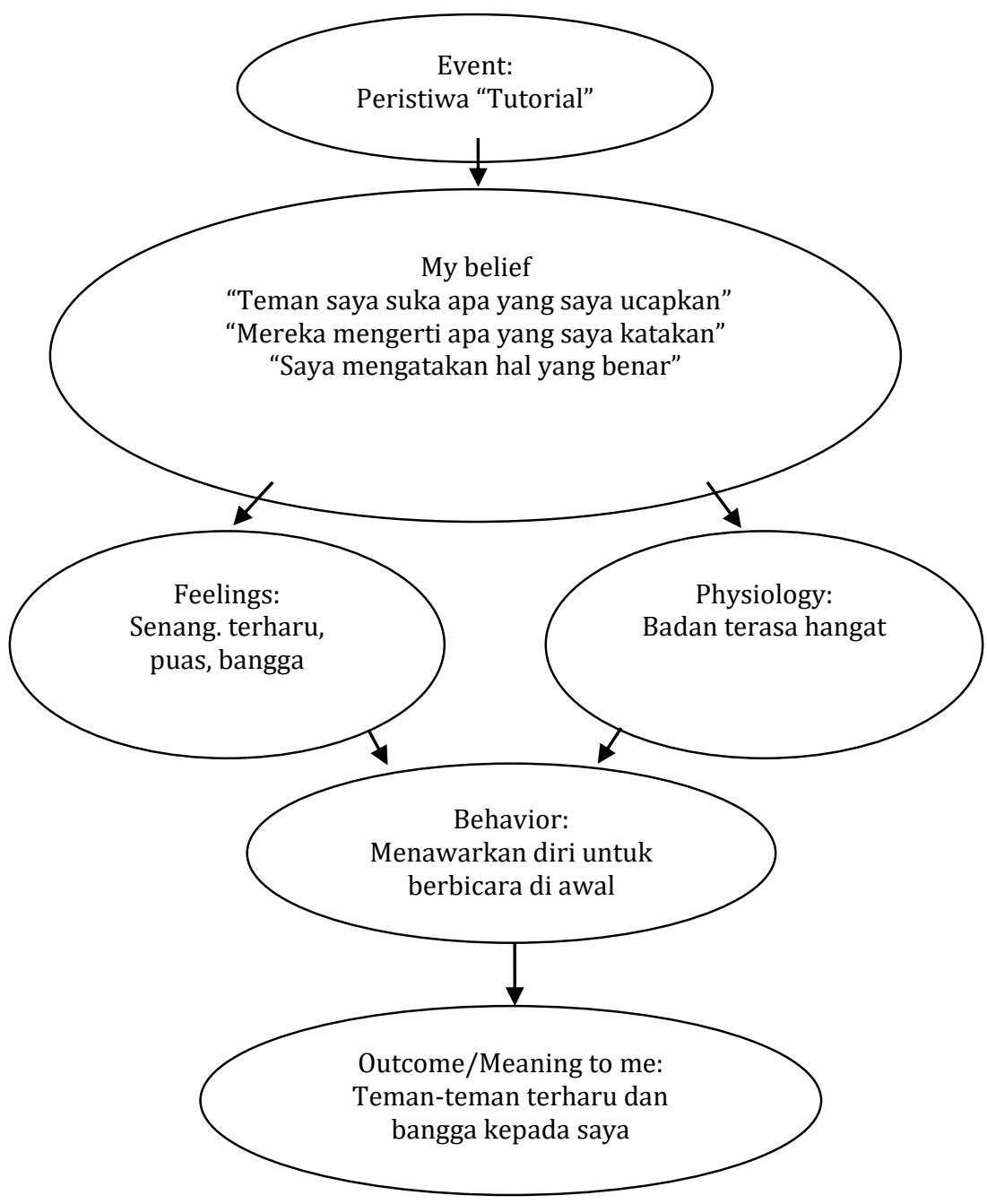

Gambar 3. Model kognitif subjek setelah konseling CBT 
Rezki Suci Qamaria | Efektivitas Konseling

\section{Simpulan}

Subjek merupakan mahasiswa semester akhir di Fakultas Kedokteran Universitas X di Yogyakarta. Subjek mengikuti proses layanan psikologi dengan keluhan bahwa dirinya merasa kesulitan menghadapi perkuliahannya. Kondisi tersebut disebabkan oleh perasaan subjek yang mudah kurang percaya diri ketika berbicara didepan umum atau berbicara dengan orang baru ditemuinya. Subjek pun merasa kondisi dirinya tersebut membuatnya memiliki sosialisasi yang terbatas. Berdasarkan keluhan subjek, peneliti kemudian melakukan proses assesmen lebih lanjut. Hasilnya adalah subjek memiliki kapasitas kecerdasan rata-rata bawah dan kondisi itu dirasakan subjek sebagai kekurangannya dan berpikir bahwa dirinya tidak sepintar teman-temannya. Subjek juga memiliki pengolahan emosi yang belum tepat. Subjek selalu memendam apa yang dipikirkan dan dirasakannya seorang diri sehingga subjek tumbuh menjadi pribadi yang tertutup dan merasa inferior akan keberadaannya di lingkungannya. Disisi lain sebenarnya subjek sudah mampu mengetahui dan mengenali apa yang menjadi kelemahan dan kelebihannya, namun sejauh ini subjek menilai kelemahan yang dimilikinya menjadi momok dirinya yang merasa tidak mampu seperti teman-temannya dalam mengikuti proses perkuliahan. Situasi juga semakin membuatnya merasa tidak aman ketika lingkungannya selalu membandingbandingkan dirinya dengan kakaknya sendiri. Subjek semakin merasa tidak memiliki daya untuk menjalani perkuliahannya dan akhirnya memiliki banyak penilaian negatif terhadap dirinya sendiri. Penilaian negatif itu tidak terlepas dari adanya pikiranpikiran negatif dan aturan/asumsi negatif yang dimiliki subjek sehingga subjek memiliki keyakinan yang negatif terhadap dirinya.

Kondisi tersebutlah yang menjadi dasar peneliti memberikan intervensi konseling cognitive-behavior therapy kepada subjek. Hasilnya adalah subjek menemukan beberapa keyakinan negatif yang membuat dirinya tidak berdaya dengan keadaan. Setelah ditemukan, subjek diarahkan untuk menemukan keyakinan alternatif lain yang positif sehingga subjek memiliki penilaian

178 | Journal An-nafs: Vol. 4 No. 2 Desember 2019 
Rezki Suci Qamaria | Efektivitas Konseling

positif kepada dirinya. Setelah melakukan proses terapi selama tiga sesi, hasilnya adalah subjek memiliki self esteem yang tinggi. subjek telah memiliki penilaian yang positif terhadap dirinya dan tidak melihat lagi kekurangan yang dimilikinya sebagai sebuah momok membuat dirinya tidak berdaya. 
Rezki Suci Qamaria| Efektivitas Konseling

\section{Daftar Pustaka}

Ayuevita, T. O., Rosra, M., \& Mayasari, S. (2014). Peningkatan Self Esteem Siswa Kelas X Menggunakan Layanan Konseling Kelompok. ALIBKIN (Jurnal Bimbingan Konseling), 3(3), 1-13. Corey, M. S., Corey, G., \& Corey, C. (2013). Groups: Process and practice. Sandiago USA: Cengage Learning.

Della. (2012). Cognitive Behavior Therapy Untuk Meningkatkan Self Esteem Pada Mahasiswa Universitas Indonesia Yang Mengalami Distres Psikologis. Jakarta: Universitas Indonesia.

Feist, J., \& Feist, G. J. (2010). Teori kepribadian. Jakarta: Salemba Humanika, 31.

Ghufron, M. N., \& Risnawita, R. (2010). Teori-teori psikologi. In Yogyakarta: Ar-Ruzz Media. Depok.

Habsy, B. A. (2017). Model konseling kelompok cognitive behavior untuk meningkatkan self esteem siswa SMK. Perspektif Ilmu Pendidikan, 31(1), 21-35.

Hunt, B., \& Guindon, M. H. (2010). Alcohol and other drug use and self-esteem in young adults. Self-Esteem across the Lifespan: Issues and Interventions, 219-229.

Indrawsari, P. (2012). Modifikasi kognitif perilaku untuk meningkatkan self esteem remaja (dengan teknik restrukturisasi kognitif, visualisasi, dan memperbaiki penampilan diri). Tesis. Universitas Indonesia.

Islamiah, N., Daengsari, D. P., \& Hartiani, F. (2015). Cognitive behavior therapy untuk meningkatkan self-esteem pada anak usia sekolah. Jurnal Ilmu Keluarga \& Konsumen, 8(3), 142152.

Kumalasari, D. (2017). Konsep Behavioral Therapy dalam Meningkatkan Rasa Percaya Diri pada Siswa Terisolir. HISBAH: Jurnal Bimbingan Konseling Dan Dakwah Islam, 14(1), 15-24.

Latipun. (2008). Psikologi eksperimen. Malang: UPT Penerbitan Universitas Muhammadiyah Malang.

Lumongga, D. R. N. (2016). Depresi: tinjauan psikologis. Jakarta: Kencana.

Pandu Wiyata, R. (2019). Upaya Meningkatkan Percaya Diri melalui Konseling Kelompok Teknik Pemodelan Kognitif pada Pengurus Osis Sman 1 Plumpang. Jurnal BK UNESA, 9(2), 3339.

Rosenberg, M. (2015). Society and the adolescent self-image. United

180 | Journal An-nafs: Vol. 4 No. 2 Desember 2019 
States of America: Princeton university press.

Saputra, W. N. E., \& Prasetiawan, H. (2018). Meningkatkan Percaya Diri Siswa melalui Teknik Cognitive Defusion. Jurnal Kajian Bimbingan Dan Konseling, 3(1), 14-21.

Shobabiya, M., \& Prasetyaningrum, J. (2017). Konseling Kognitif Untuk Mengurangi Kecemasan Akademik Pada Siswa SMP Kelas 7. Prosiding SEMNAS Penguatan Individu Di Era Revolusi Informasi, 223-230. https://doi.org/978-602-361-068-6

Situmorang, D. D. B. (2018). Mahasiswa mengalami academic anxiety terhadap skripsi? Berikan konseling cognitive behavior therapy dengan musik. Jurnal Bimbingan Dan Konseling Ar-Rahman, 3(2), 31-42.

Srisayekti, W., \& Setiady, D. A. (2015). Harga-diri (Self-esteem) Terancam dan Perilaku Menghindar. Jurnal Psikologi, 42(2), 141-156.

Yin, R. K. (2017). Case study research and applications: Design and methods. CA: Sage publications.

Wilding, C \& Milne, A. (2008). Cognitive behavioral therapy. United State: The McGraw-Hill Companies. 